\title{
ANALISIS FLUKTUASI DEBIT AIR AKIBAT PERUBAHAN PENGGUNAAN LAHAN DI KAWASAN PUNCAK KABUPATEN BOGOR
}

\author{
Analysis of Water Discharge Fluctuation Due to Land Use Change \\ in Puncak Area, Bogor District \\ Yunita Lisnawati dan/and Ari Wibowo \\ Pusat Penelitian dan Pengembangan Hutan Tanaman \\ Kampus Balitbang Kehutanan, Jl. Gunung Batu No. 5 Bogor 16610 \\ Telp. (0251) 8631238, Fax. (0251) 75200052
}

Naskah masuk : 31 Agustus 2009; Naskah diterima : 18 Agustus 2010

\begin{abstract}
Puncak area located in Sub catchment of Ciliwung Hulu is an important water catchment area for the city of Jakarta. Currently with the dynamic change of land use especially for settlement, it has resulted in changes of the maximum-minimum water discharge. This study therefore had the objective to analyze changes of land use between the years of 1995-2003, especially in relation with changes of the maximum-minimum water discharge in the Puncak area of Bogor District. Spatial analysis has been done by using maps of land use for the years of 1995-2003 based on Landsat ETM+ satellite images and Geographic Information Systems (GIS). Analysis of attribute data applied Multiple Correlation Analysis and Multiple Regression Analysis. The results of spatial analysis showed that changes of land use in Puncak area during the years of 1995-2003 were caused by tendency of changes from mix garden area into settlement. Multiple correlation analysis proved high correlation and negative correlation between forest cover area and maximum-minimum fluctuation of water discharge. The Results of multiple regression analysis also showed that the forest cover could reduce the fluctuation of maximumminimum water discharge by $0.027 \mathrm{~m} 3 /$ second, with one hectare increase offorest cover.
\end{abstract}

Keywords: Landsat ETM' satellite images, water discharge fluctuation, Puncak area, land use

\begin{abstract}
ABSTRAK
Kawasan Puncak yang terletak di Sub DAS Ciliwung Hulu merupakan daerah tangkapan air yang penting bagi kota Jakarta. Namun saat ini dengan terjadinya perubahan penggunaan lahan yang sangat dinamis, terutama peningkatan penggunaan untuk pemukiman telah berdampak pada perubahan debit air maksimum-minimum. Oleh karena itu penelitian ini bertujuan untuk menganalisis perubahan penggunaan lahan antara tahun 1995-2003, dalam hubungannya dengan perubahan debit air maksimumminimum di kawasan Puncak Kabupaten Bogor. Analisis spasial dilakukan dengan menggunakan peta penggunaan lahan tahun 1995-2003 berdasarkan citra satelit landsat ETM+, dan Sistem Informasi Geografis (SIG). Analisis data atribut menggunakan Analisis Korelasi Berganda dan Analisis Regresi Berganda. Hasil analisis spasial menunjukkan bahwa perubahan penggunaan lahan di kawasan Puncak pada periode tahun 1995-2003 cenderung didominasi oleh perubahan lahan kebun campuran menjadi pemukiman. Analisis korelasi berganda menunjukkan adanya korelasi yang cukup tinggi dan berkorelasi negatif antara luas hutan dan selisish debit maksimum-minimum. Hasil analisis regresi berganda menunjukkan bahwa hutan mampu menurunkan selisih debit air maksimum-minimum sebesar 0,027 $\mathrm{m} 3 /$ detik, jika luasan hutan naik sebesar satu hektar.
\end{abstract}

Kata kunci : citra satelit landsat ETM', fluktuasi debit air, kawasan Puncak, penggunaan lahan 


\section{PENDAHULUAN}

Kawasan Puncak telah dianggap sebagai wilayah hinterland, sebagai wilayah penyangga kehidupan penduduk di wilayah DAS bagian hilir, yaitu Bogor, Depok dan Daerah Khusus Ibu Kota (DKI) Jakarta, baik secara ekonomi maupun secara ekologi. Kesinambungan fungsi Bogor, Depok dan DKI Jakarta sebagai suatu ekosistem sangat tergantung pada kawasan ini, terutama dalam hal ketersediaan sumberdaya air. Ketersediaan sumberdaya air ini terutama sangat ditentukan oleh DAS Ciliwung Hulu. DAS ini masuk dalam wilayah kecamatan Ciawi, Megamendung dan Cisarua di Kabupaten Bogor.

Kondisi topografi DAS Ciliwung Hulu dengan panorama yang menarik, yang menyebabkan tumbuhnya pusat berbagai macam kegiatan. Terutama berkembangnya daerah pariwisata dengan segala bentuk aneka ragam usahanya, serta daerah pemukiman. Kedua hal tersebut cenderung menimbulkan alihfungsi kawasan hutan dan pertanian menjadi kawasan budidaya dan pemukiman. Perubahan penggunaan lahan akan mengakibatkan perubahan terhadap kapasitas infiltrasi dan tampungan permukaan atau gabungan keduanya, dan efek selanjutnya adalah mempengaruhi aliran permukaan. Penurunan kapasitas infiltrasi lebih berpengaruh terhadap volume aliran permukaan, sedangkan tampungan permukaan lebih berpengaruh pada pelambatan (delay) aliran permukaan untuk mengalir sampai outlet DAS. Tumbuhan dengan berbagai jenis vegetasi dalam kondisi iklim tertentu, sangat penting artinya dalam siklus hidrologi. Apabila terjadi proses alih fungsi lahan pada hutan atau adanya pengembangan kawasan menjadi lahan pemukiman maka kondisi hidrologi yang ada umumnya berubah dengan drastis. Dari uraian tersebut maka terlihat peran atau fungsi lahan hutan yang sangat besar dalam memperkecil aliran permukaan sehingga debit maksimum akan dapat diperkecil sedangkan di sisi lain tampungan air tanah akan lebih banyak untuk dapat menjaga ketersediaan jumlah aliran air tanah sepanjang tahun.

Penelitian ini bertujuan untuk menganalisis keterkaitan perubahan penggunaan lahan terhadap selisih debit maksimumminimum Sungai Ciliwung di Sub DAS Ciliwung Hulu.

\section{BAHAN DAN METODE}

\section{A. Bahan dan Alat}

Bahan yang digunakan dalam penelitian ini meliputi :

1. Peta Perubahan Penggunaan Lahan (Ciawi, Megamendung dan Cisarua) tahun 1995, 1997, 2001, dan 2003. diperoleh dari analisa citra. Kawasan bervegetasi permanen terdiri dari hutan, kebun teh dan kebun campuran, sedangkan kawasan tidak permanen terdiri dari ladang, semak dan sawah. Metode membedakan masing-masing kawasan di dalam citra landsat dilakukan berdasarkan warna dan tekstur, dengan demikian telah diperoleh hasil karakterisasi lahan sebagai berikut:

Hutan ditemukan dengan bentuk dan pola yang tidak teratur dengan ukuran yang cukup luas, menyebar terkadang bergerombol, berwarna hijau tua sampai gelap dengan tekstur relatif kasar.

Kebun teh tampak berwarna hijau muda dan memiliki tekstur halus.

Kebun campuran memiliki tekstur relatif kasar, berwarna hijau bercampur dengan sedikit magenta, bentuk dan pola memanjang dijumpai pada lembah dan sepanjang tanggul sungai, seringkali bercampur dengan pemukiman.

Ladang/tegalan ditunjukkan dengan tekstur halus, hijau tua agak terang, bercampur dengan sedikit magenta dan kuning.

Semak/belukar ditunjukkan dengan tekstur yang relatif halus dari pada hutan, berwarna hijau lebih agak terang dibandingkan hutan.

Sawah ditunjukkan dengan warna putih hingga merah jambu dengan tekstur halus.

Sawah ditunjukkan dengan tekstur kasar, warna hijau agak gelap bercampur dengan magenta dan biru.

2. Data debit maksimum - minimum Sungai Ciliwung, Bendung Katulampa dari Tahun 1995- 2003, data sekunder dari Balai Pengelolaan Sumberdaya Air CiliwungCisadane, Bogor.

\section{B. Metode Penelitian}

Operasi tumpang tindih (overlay) dilakukan menggunakan data digital peta penggunaan/penutupan lahan dengan bantuan 
Arcview 3.2. Operasi tumpang tindih dilakukan antara peta penggunaan/penutupan lahan tahun 1995 dan 1997, 1997 dan 2001, 2001 dan 2003 serta 1995 dan 2003, yang bertujuan untuk melihat arah dan pola perubahan penggunaan/ penutupan lahan. Ekstrasi data atribut hasil dari operasi tumpang tindih ini digunakan sebagai data dalam tehnik analisis selanjutnya.

Untuk melihat keeratan hubungan perubahan penggunaan lahan terhadap debit sungai digunakan analisis korelasi berganda, Pearson's Product Moment (Walpole,1992). Perubahan penggunaan lahan dinyatakan dalam luas penutupan lahan dengan vegetasi permanen (x1), luas lahan bervegetasi tidak permanen (x2) dan pemukiman (x3), serta debit air sungai yang diwakili selisih debit maksimum - minimum $(\Delta \mathrm{Q})$. Persamaan (model) yang digunakan adalah:

$$
\mathrm{Y}=\mathrm{a}_{0}+\mathrm{b}_{1} \mathrm{X}_{1}+\mathrm{b}_{2} \mathrm{X}_{2}+\mathrm{b}_{3} \mathrm{X}_{3}
$$

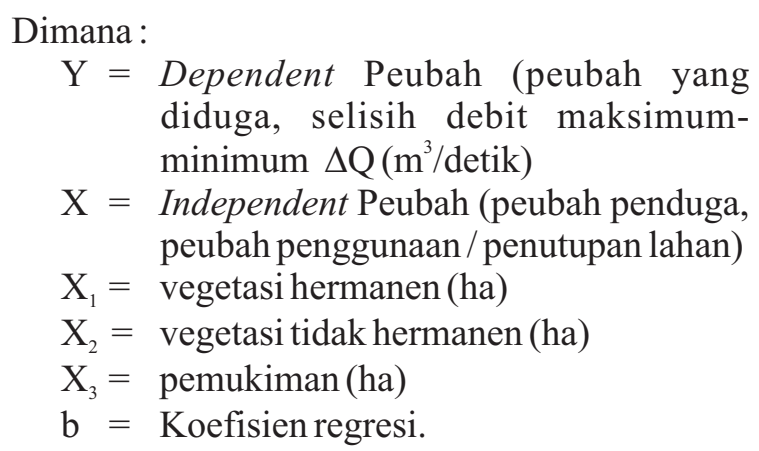

\section{HASIL DAN PEMBAHASAN}

Hasil analisis korelasi digunakan untuk menentukan peubah-peubah yang akan dijadikan model dalam regresi berganda. Peubah-peubah yang mempengaruhi selisih debit maksimumminimum tertera pada Tabel 1 .

Tabel (Table) 1. Peubah-peubah yang mempengaruhi selisih debit maksimum-minimum (Variables that affect the maximum-minimum fluctuation of water discharge)

\begin{tabular}{|c|c|c|}
\hline $\begin{array}{l}\text { Peubah } \\
\text { (Variable) }\end{array}$ & $\begin{array}{l}\text { Koefisien } \\
\text { (Coefficient) }\end{array}$ & p-level \\
\hline $\mathrm{S}=17,51 ; \alpha=0,05 ; \mathrm{R}-\mathrm{Sq}=99,9 \% ; \mathrm{R}-\mathrm{Sq}(\operatorname{adj})=99,9 \%$ & & \\
\hline Bervegetasi permanen (X1) & $-0,027$ & 0,005 \\
\hline Bervegetasi tidak permanen (X2) & $-0,108$ & 0,000 \\
\hline Pemukiman (X3) & $+0,072$ & 0,000 \\
\hline
\end{tabular}

Hasil analisis regresi berganda pada taraf $\alpha=0,05$ menunjukkan peubah-peubah yang berpengaruh terhadap selisih debit maksimumminimum (Y), dimodelkan dalam persamaan sebagai berikut:

$$
Y=641,4-0,027 X_{1}-0,108 X_{2}+0,072 X_{3}
$$

Persamaan tersebut merupakan model yang menggambarkan hubungan antara $\mathrm{Y}=$ selisih debit maksimum-minimum (m3/detik) dengan X1 (luas lahan yang bervegetasi permanen (ha), X2, luas lahan bervegetasi tidak permanen (ha) dan X3, luas pemukiman (ha). Lahan bervegetasi permanen adalah hutan, kebun teh dan kebun campuran, sedangkan lahan bervegetasi tidak permanen terdiri dari ladang, semak dan sawah. Berdasarkan penelitian telah diperoleh data luasan lahan-lahan tersebut dari tahun 1995 sampai 2003 (Tabel 2.).
Persamaan pada tabel 2 menunjukkan bahwa luas lahan bervegetasi permanen memiliki hubungan berbanding terbalik terhadap selisih debit maksimum-minimum, begitu juga untuk lahan yang bervegetasi tidak permanen. Semakin kecil luas lahan yang bervegetasi maka akan semakin besar selisih debit maksimum minimum, begitu juga sebaliknya. Namun, untuk lahan pemukiman mempunyai hubungan berbanding lurus dengan selisih debit maksimum-minimum, semakin luas lahan pemukiman maka akan semakin besar selisih debit maksimum-minimum. Artinya pada lahan bervegetasi (permanen dan tidak permanen), adanya perubahan lahan akan menimbulkan dampak yang cukup besar terhadap debit maksimum-minimum.

Khusus untuk lahan bervegetasi, jika terjadi penurunan jumlah (luas lahan) bervegetasi permanen sebesar satu hektar maka akan 
meningkatkan selisih debit maksimumminimum sebesar $0,027 \mathrm{~m} 3 /$ detik, dengan asumsi luas vegetasi tidak permanen dan pemukiman tetap, namun jika terjadi penurunan vegetasi tidak permanen sebesar satu hektar maka akan meningkatkan selisih debit maksimumminimum sebesar 0,108 $\mathrm{m} 3$ /detik, dengan asumsi luas lahan vegetasi permanen dan pemukiman tetap. Sedangkan jika terjadi kenaikan luas lahan pemukiman sebesar satu hektar maka akan meningkatkan selisih debit maksimum-minimum sebesar $0,0723 \mathrm{~m} 3$ /detik dengan asumsi luas lahan vegetasi permanen dan tidak permanen tetap.

Tabel (Table) 2. Luas lahan vegetasi permanen dan tidak permanen serta pemukiman (Area of permanent, non-permanent vegetation and settlement)

\begin{tabular}{|c|c|c|c|c|c|c|}
\hline \multirow{3}{*}{ Katagori lahan (Land category) } & \multicolumn{6}{|c|}{ Luas lahan (Land area) } \\
\hline & \multicolumn{2}{|c|}{1995} & \multicolumn{2}{|c|}{2003} & \multicolumn{2}{|c|}{$\begin{array}{c}\text { Luas perubahan } \\
\text { lahan } \\
\text { (Land change area) }\end{array}$} \\
\hline & (ha) & $(\%)$ & (ha) & $(\%)$ & (ha) & $(\%)$ \\
\hline Vegetasi Permanen $\left(\mathbf{X}_{1}\right)$ & 14672.61 & 79.48 & 8512.56 & 59.35 & -6160.05 & 20.13 \\
\hline - Hutan & 6454,08 & 34,96 & 5180,85 & 28,07 & -1273.23 & -6.89 \\
\hline - Kebun Teh & 3484,89 & 18,88 & 2886,39 & 15,64 & -598.50 & -3.24 \\
\hline - Kebun Campuran & 4733,64 & 25,64 & 445,32 & 15,64 & -4288.32 & -10.00 \\
\hline Vegetasi Tidak Permanen $\left(\mathrm{X}_{2}\right)$ & 2879.91 & 6.82 & 2733.48 & 14.812 & +1475.46 & +7.992 \\
\hline - Ladang & 1171,53 & 6,35 & 2713,32 & 14,70 & +1541.79 & +8.35 \\
\hline - Semak & 83,07 & 0,45 & 0,45 & 0,002 & -82.62 & -0.448 \\
\hline - Sawah & 3,42 & 0,02 & 19,71 & 0,11 & +16.29 & +0.09 \\
\hline Pemukiman $\left(\mathrm{X}_{3}\right)$ & 1621,89 & 8,79 & $\mathbf{5 9 5 7 , 5 5}$ & 32,28 & +4335.66 & +23.49 \\
\hline
\end{tabular}

Keterangan (Remark) : (-) : Berkurangnya luasan (Area decrease)

$(+)$ : Bertambahnya luasan (Area increasr)

Apabila selisih debit maksimum dan minimum tinggi, yang berarti pada musim hujan dengan intensitas curah hujan yang tinggi akan berakibat melimpahnya aliran permukaan dan sebaliknya pada musim kemarau. Hal tersebut akan berakibat banjir pada musim penghujan dan kekeringan pada musim kemarau. Fluktuasi aliran debit antara kedua musim yang tajam mengindikasikan terganggunya fungsi DAS serta adanya degradasi kualitas DAS. Fahrudin (2003) menyatakan bahwa proses yang terjadi dalam DAS dipengaruhi oleh faktor hidrologi, geomorfologi, geologi, topografi, klimatologi, tanah dan penggunaan lahan. Sementara itu aliran permukaan terjadi bila curah hujan melebihi laju infiltrasi tanah dan tampungan permukaan tanah. Hutan di kawasan Puncak adalah sangat penting karena kawasan tersebut merupakan daerah yang berbukit, bergelombang dan bergunung-gunung dengan ketinggian mulai dari 330 - 3.002 meter di atas permukaan laut, serta lerengnya berkisar antara $8-45 \%$ yang akan berdampak besar terhadap tingkat erosinya (RTRW Kabupaten Bogor, 2000).

Menurut Morgan (1986) dalam Pratiwi (2004), efektifitas tanaman penutup dalam mengurangi erosi dan aliran permukaan dipengaruhi oleh tumbuhan dan bentuk tajuk (kanopi), kerapatan tanaman dan kerapatan sistem perakaran. Semakin tinggi tempat jatuh butiran hujan makin tinggi pula energi kinetiknya. Sementara itu, kerapatan tanaman berfungsi mempengaruhi besarnya luasan lahan yang dapat ditutupi oleh tumbuhan. Semakin rapat tanaman (vegetasi) yang ada di permukaan lahan semakin kecil kemungkinan terjadinya erosi. Sedangkan kerapatan sistem perakaran tanaman/vegetasi menentukan efektifitas tanaman dalam membantu pemantapan agregat, yang berarti pula meningkatkan besar kecilnya laju dan kapasitas infiltrasi, sehingga meningkatnya porositas tanah dan dapat mengurangi energi perusak aliran permukaan dan dapat mengurangi aliran permukaan. Oleh karena itu peran hutan sangat besar dalam memperkecil aliran permukaan sehingga debit maksimum akan dapat diperkecil sedangkan disisi lain tampungan air tanah akan lebih banyak sehingga debit minimum akan dapat diperbesar untuk dapat menjaga ketersediaan air tetap terjamin sepanjang tahun. 
Seperti halnya dengan hutan, keberadaan kebun teh juga harus dipertahankan karena mempunyai peran yang khas yaitu sebagai pengatur tata air, pencegahan banjir dan erosi. Pohon teh mempunyai sifat perakaran yang dalam, akar serabut panjang, dan kerapatan akar tinggi, sehingga baik untuk tindakan konservasi tanah dan air, yaitu sebagai pencegah erosi.

Apabila laju pengurangan kebun teh tidak dapat ditekan, akan berdampak negatif terhadap lingkungan, baik yang dirasakan oleh wilayah tersebut maupun wilayah hilirnya. Berdasarkan hasil konfirmasi lapangan, bahwa warga sekitar kebun teh sudah merasakan mulai berkurangnya sumber air, seiring dengan banyaknya kebun teh yang terkonversi menjadi penggunaan lainnya seperti villa.

Kebun campuran ditanami dengan berbagai macam tanaman yang diatur secara spasial dan urutan temporal. Jenis tanaman yang dominan adalah tanaman tahunan. Sehingga keberadaannya sama dengan hutan dan kebun teh yang harus dipertahankan untuk menjaga tata air di kawasan Puncak sehingga frekwensi kejadian banjir di kawasan hilirnya dapat ditekan.

Adanya konversi lahan hutan menjadi lahan pertanian, dimana pada saat pembukaannya menggunakan alat berat yang bertujuan meratakan tanah dapat membuat lapisan tanah yang subur hilang sehingga mempengaruhi sifat fisik tanah. Selain itu juga dapat merusak struktur dan tekstur tanah, memperbesar jumlah dan kecepatan aliran permukaan akibat daya serap (infiltrasi) berkurang atau terhambat. Keberadaan lahan pertanian di kawasan Puncak disatu sisi adalah untuk meningkatkan produksi pangan, namun di sisi lain apabila keberadaannya kurang dapat dikendalikan akan dapat menurunkan fungsi hidrologis mengingat kondisi topografi kawasan Puncak yang sebagian besar bergelombang, berbukit dan bergunung dengan kecuraman lereng antara 8 - 45 persen. Agar supaya keberadaan lahan pertanian (ladang dan sawah) tetap menjamin fungsi hidrologis secara baik, maka lahan yang diusahakan sebaiknya yang cenderung datar atau dengan menggunakan teras maupun mulsa.

Adanya penambahan pemukiman yang berlangsung dengan cepat di kawasan Puncak mengakibatkan bertambahnya daerah kedap air sehingga mengurangi daya serap atau infiltrasi air ke dalam tanah. Apabila perluasan areal pemukiman tidak dapat dikendalikan maka setiap terjadi curah hujan yang cukup besar intensitasnya maka dapat lebih meningkatkan nilai debit maksimum dan sebaliknya bila curah hujan rendah debit minimum akan semakin turun. Hal tersebut dapat ditunjukkan dengan fakta bahwa curah hujan di Sub DAS Ciliwung Hulu dari tahun 1995 - 2003 cenderung turun, namun debit maksimum cenderung meningkat dan selisih debit maksimum - minimum cenderung meningkat pula. Kondisi seperti tersebut dapat menjadi indikasi berkurangnya fungsi kawasan Sub DAS Ciliwung Hulu sebagai kawasan lindung dan wilayah peresapan air. Kondisi kawasan Sub DAS Ciliwung Hulu juga dapat ditunjukkan dengan rasio debit maksimum minimum sungai Ciliwung (Tabel 3). Rasio debit maksimum dan minimum menggambarkan fluktuasi debit aliran sebagai respon dari curah

Tabel(Table) 3. Debit Minimum, Maksimum Sungai Ciliwung dan Jumlah Curah Hujan Stasiun Pengamatan Bendung Katulampa (Minimum, maximum discharge and total rainfall of Ciliwung river at Observation Station of Katulampa Dam)

\begin{tabular}{|c|c|c|c|c|c|}
\hline $\begin{array}{c}\text { Tahun } \\
(\text { Year })\end{array}$ & $\begin{array}{c}\text { Debit minimum } \\
\left(\mathrm{m}^{3} / \text { detik }\right) \\
(\text { Minimum } \\
\text { discharge })\end{array}$ & $\begin{array}{c}\text { Debit maksimum } \\
\left(\mathrm{m}^{3} / \text { detik }\right) \\
(\text { Maximum } \\
\text { discharge })\end{array}$ & $\begin{array}{c}\text { Selisih Debit } \\
\text { maksimum- } \\
\text { minimum } \\
\left(\mathrm{m}^{3} / \text { detik }\right) \\
(\Delta \text { Maximum- } \\
\text { Minimum } \\
\text { Discharge })\end{array}$ & $\begin{array}{c}\text { Rasio Debit } \\
\text { maksimum- } \\
\text { minimum } \\
(\text { Ratio of } \\
\text { maximum- } \\
\text { minimum } \\
\text { discharge })\end{array}$ & $\begin{array}{c}\text { Jumlah } \\
\text { curah } \\
\text { hujan } \\
(\text { Total } \\
\text { rainfall }) \\
\left(\mathrm{mm}^{3} / \mathrm{th}\right)\end{array}$ \\
\hline 1995 & 1,71 & 244,20 & 242,49 & 142,64 & 4.426 \\
1997 & 1,22 & 244,20 & 242,98 & 199,51 & 2.690 \\
2001 & 3,46 & 411,68 & 408,22 & 118,98 & 4.178 \\
2003 & 1,22 & 274,73 & 273,50 & 224,44 & 3.875 \\
\hline $\begin{array}{c}\text { Rata- } \\
\text { rata }\end{array}$ & 1,91 & 293,70 & 291,80 & 171,39 & $3.792,25$ \\
\hline
\end{tabular}


hujan yang masuk ke dalam outlet DAS. Nilai rasio ini sering digunakan sebagai indikator keberhasilan pengelolaan DAS di daerah yang relatif basah dan hujan relatif terdistribusi sepanjang tahun.
Berdasarkan kriteria Departemen Kehutanan tahun 2002 mengklasifikasikan kualitas DAS dengan menggunakan rasio debit maksimum-minimum tahunan, seperti disajikan pada Tabel 4 .

Tabel (Table) 4. Kriteria kualitas DAS berdasarkan debit tahunan(Criteria of watershed quality based on annual discharge)

\begin{tabular}{|l|c|c|}
\hline $\begin{array}{c}\text { Kualitas DAS } \\
\text { (Watershed Quality) }\end{array}$ & Q max/Q min & Indeks \\
\hline Sangat Baik & & 1 \\
Baik & $50-150$ & 2 \\
Sedang & $150-250$ & 3 \\
Jelek & $250-500$ & 4 \\
Sangat Jelek & $>500$ & 5 \\
\hline
\end{tabular}

Berdasarkan Tabel 3 di atas, diketahui bahwa kualitas DAS di Sub DAS Ciliwung Hulu rata-rata termasuk kriteria Sedang. Oleh karena itu, untuk mencegah penurunan kualitas DAS lebih lanjut, maka areal yang bervegetasi harus tetap dipertahankan, dan areal pemukiman harus ditekan.

\section{KESIMPULAN}

Perubahan luasan lahan yang bervegetasi permanen, bervegetasi tidak permanen dan pemukiman di kawasan Puncak mempunyai hubungan yang sangat erat dengan selisih debit maksimum-minimum, dengan pola hubungan: $\mathrm{Y}$ $=641,4-0,027 \mathrm{X} 1-0,108 \mathrm{X} 2+0,072 \mathrm{X} 3$, dimana : $\mathrm{Y}=$ Selisih debit maksimumminimum (m3/detik) dan X1, X2 ,X3 masingmasing adalah luas lahan bervegetasi permanen, tidak permanen, dan pemukiman dalam hektar.

\section{DAFTAR PUSTAKA}

Balai Pengelolaan Sumberdaya Air CiliwungCisadane, Bogor. 2004. Data debit maksimum - minimum Sungai Ciliwung, Bendung Katulampa.
Fakhrudin, M. 2003. Kajian Respon Hidrologi akibat Perubahan Penggunaan Lahan DAS Ciliwung dengan Model Sedimot II. Tesis. Pasca Sarjana. IPB.

Hardiana, D. 1999. Simulasi Dampak Perubahan Guna Lahan terhadap Perubahan Limpasan Air Permukaan. Studi Kasus : Sub DAS Cipamingkis di Kawasan Jonggol. Skripsi. Institut Tehnologi Bandung.

Pemerintah Kabupaten Daerah Tingkat II Bogor. 2000. Rencana Tata Ruang Wilayah Kabupaten Daerah Tingkat II Bogor. Bogor.

Pratiwi. 2004. Keragaman Jenis Pohon dan Konservasi Tanah dan Air di Kawasan Taman Nasional. Prosiding Pemanfaatan Jasa Hutan dan Non Kayu Berbasis Masyarakat sebagai Solusi Peningkatan Produktivitas dan Pelestarian Hutan. Departemen Kehutanan.

Walpole, R.E. 1992. Pengantar Statistika. Terjemahan. PT. Gramedia Pustaka Utama. Jakarta. 